\title{
Estimates of Tree Biomass, and Its Uncertainties Through Mean-of-Ratios, Ratio-of-Means, and Regression Estimators in Double Sampling: A Comparative Study of Mecrusse Woodlands
}

\author{
Tarquinio Mateus Magalhães ${ }^{1,2, *}$, Thomas Seifert ${ }^{2}$ \\ ${ }^{1}$ Department of Forest Engineering, Eduardo Mondlane University, Main Campus, Maputo, Mozambique \\ ${ }^{2}$ Department of Forest and Wood Science, University of Stellenbosch, Stellenbosch, South Africa
}

Email address:

tarqmag@yahoo.com.br (T. M. Magalhães), seifert@sun.ac.za (T. Seifert)

\section{To cite this article:}

Tarquinio Mateus Magalhães, Thomas Seifert. Estimates of Tree Biomass, and Its Uncertainties Through Mean-of-Ratios, Ratio-of-Means, and Regression Estimators in Double Sampling: A Comparative Study of Mecrusse Woodlands. American Journal of Agriculture and Forestry. Vol. 3, No. 5, 2015, pp. 161-170. doi: 10.11648/j.ajaf.20150305.11

\begin{abstract}
Frequently, biomass expansion factors (BEFs), the respective biomass densities, and their uncertainties are computed without taking into account the appropriate estimators. The objective of this study was to compare the estimates of BEF, BEF-based biomass densities, and their uncertainties using different estimators (mean-of-ratios, ratio-of-means, and regression estimators) in double sampling. Our results demonstrated that increased uncertainty is associated with regressionbased biomass densities, and that the computation of BEF using merchantable timber volume should utilize regression estimators, not the usual ratio estimators, which preferably, should be avoided altogether, as they are found to be subjective and more susceptible to errors and personal judgment.
\end{abstract}

Keywords: Tree Component, Additivity, Belowground Biomass, Aboveground Biomass, Biomass Expansion Factor (BEF), Androstachys Johnsonii Prain

\section{Introduction}

In double sampling, the variables of interest (e.g., biomass) are determined through auxiliary variables, either by ratio estimators or regression estimators [1-6]. The ratio estimators, in turn, are divided into two classes: mean-ofratios and ratio-of-means estimators $[1,3,4]$. When the regression line of the variable of interest (e.g., component biomass) and the auxiliar variable (e.g., stem volume) does not pass through the origin, the regression estimators are preferable $[1-4,6]$. Ratio estimators are appropriate when the regression takes the form of a straight line passing through the origin [1-6].

An example of ratio estimators in forestry is the estimate of biomass density with the aid of biomass expansion factor $(\mathrm{BEF})$, where $\mathrm{BEF}$ is the ratio. Vegetation BEFs can be estimated either by mean-of-ratios [7-9] or by ratio-of-means [10-14].

BEF values are generally calculated from the ratio of tree component or total tree biomass to stem volume [7-14] or merchantable timber volume [15-17]. When BEF values are calculated using the first option (using stem volume), if stem volume is zero, then concurrently, tree component biomass is zero; therefore, the ratio estimators are deemed appropriate $[1,3-5]$. In the second option, however, merchantable timber volume can be zero when a tree component biomass is nonzero; e.g., merchantable timber volume, defined as the volume of the stem excluding the portion with diameter $<$ $7 \mathrm{~cm}[11,18,19]$, and trees with DBH $<7 \mathrm{~cm}[20]$ can be zero when the stem biomass or other component biomass is nonzero; therefore, regression estimators are preferable [1-6] over ratio estimators. Nevertheless, in the second case, the BEFs and respective biomasses are computed using ratio estimators [15-17], which may lead to biased estimates.

The computation of uncertainties in double sampling depends on the estimators used, otherwise the uncertainties may be under- or overestimated. In BEF-based biomass estimation, those uncertainties are mainly attributed to BEF estimates [16], and thus represent a major gap in biomass and carbon accounting at regional and national levels [19]. 
Therefore, this study was aimed at comparing estimates of $\mathrm{BEF}$ and BEF-based biomass densities, as well as their uncertainties, using different estimators (mean-of-ratios, ratio-of-means, and regression estimators) in double sampling.

\section{Material and Methods}

\subsection{Study Area}

Mecrusse is a forest type characterized by the dominant canopy species Androstachys johnsonii Prain, the relative cover of which varies from $80 \%$ to $100 \%$ [21]. In Mozambique, mecrusse woodlands are mainly found in Inhambane and Gaza provinces in the Massangena, Chicualacuala, Mabalane, Chigubo, Guijá, Mabote, Funhalouro, Panda, Mandlakaze, and Chibuto districts. The easternmost mecrusse forest patches, located in Mabote, Funhalouro, Panda, Mandlakaze, and Chibuto districts, were defined as the study area and encompassed 4,502,828 ha [22], of which 226,013 ha $(5 \%)$ were mecrusse woodlands. The climate throughout the study region is dry tropical, with the exception of humid tropical areas in western Panda and southwestern Mandlakaze districts [22-27]; their warm or rainy season occurs from October to March, and their cool or dry season occurs from March to September [23-27]. More description on Androstachys johnsonii Prain and mecrusse woodlands can be foud in Magalhães [28] and Magalhães and Seifert [29-32].

The mean annual temperature generally exceeds $24{ }^{\circ} \mathrm{C}$, and mean annual precipitation varies from 400 to $950 \mathrm{~mm}$ [22-27]. According to the United States Food and Agriculture Organization (FAO) classification [33], soils are mainly Ferralic Arenosols across more than $70 \%$ of the study region [22]. Arenosols, Umbric Fluvisols, and Stagnic soils are predominant in the northernmost part of the study region [22]. There is a shortage of water resources and precipitation throughout the study region; only Chibuto and Mandlakaze districts have water resources [22-27], either from precipitation or from lakes and rivers.

\subsection{Data Collection}

We used a two-phase sampling design to determine stem volume and biomass. In the first phase, we measured diameter at breast height (DBH) and stem height of 3574 trees $\left(m_{1}\right)$ within 23 randomly located circular plots $(20 \mathrm{~m}$ radius) for estimation of stem volume; only trees with $\mathrm{DBH} \geq$ $5 \mathrm{~cm}$ were considered. In the second phase, 93 trees $\left(m_{2}\right)$ with DBHs varying from 5 to $32 \mathrm{~cm}$ were randomly selected from those analysed during the first phase for destructive measurement of biomass and stem volume. The felled trees were divided into the following components: (1) taproot; (2) lateral roots; (3) root system $(1+2)$; (4) stem wood; (5) stem bark; (6) stem $(4+5) ;(7)$ branches; (8) foliage; (9) crown $(6$ $+7)$; $(10)$ shoot system $(6+9)$; and $(11)$ whole tree $(3+10)$. Tree components were sampled and the dry weights estimated as follows.

\subsubsection{Root System}

The stump height was predefined as being $20 \mathrm{~cm}$ for all trees and considered as part of the taproot, as recommended by Parresol [34] and because in larger $A$. johnsonii trees this height $(20 \mathrm{~cm})$ is affected by root buttress; therefore, the root collar was also considered part of the taproot. The root system was divided into 3 sub-components: fine lateral roots, coarse lateral roots, and taproot. Lateral roots with a diameter at insertion point on the taproot $<5 \mathrm{~cm}$ were considered fine roots, and those with diameters $\geq 5 \mathrm{~cm}$ were considered coarse roots.

First, the root system was partially excavated to the first node, using hoes, shovels, and picks, to expose the primary lateral roots (Figure 1a, b). The primary lateral roots were numbered and separated from the taproot with a chainsaw (Figure 1a, b), then removed from the soil, one by one. This procedure was repeated in the subsequent nodes until all primary roots were removed from the taproot and the soil. Finally, the taproot was excavated and removed (Figure 1c, d). The complete removal of the root system was relatively easy because $90 \%$ of the lateral roots of $A$. johnsonii are located in the first node, which is located close to ground level (Figure 1a, b); the lateral roots grow parallel to the ground level (they do not grow downwards); and because the taproots had, at most, only 4 nodes and at least 1 node (at ground level).

Fresh weight was obtained for the taproot, each coarse lateral root, and all fine lateral roots. A sample was obtained from each sub-component, fresh weighed, marked, packed in a bag, and brought to the laboratory for oven drying. For the taproot, the samples consisted of two discs: one taken immediately beneath ground level, and another from the middle of the taproot. For the coarse lateral roots, two discs were also taken, one from the insertion point on the taproot, and another from its middle. For fine roots, the sample was 5 to $10 \%$ of the fresh weight of all fine lateral roots. Oven drying of all samples was performed at $105^{\circ} \mathrm{C}$ to constant weight; hereafter, referred to as dry weight.

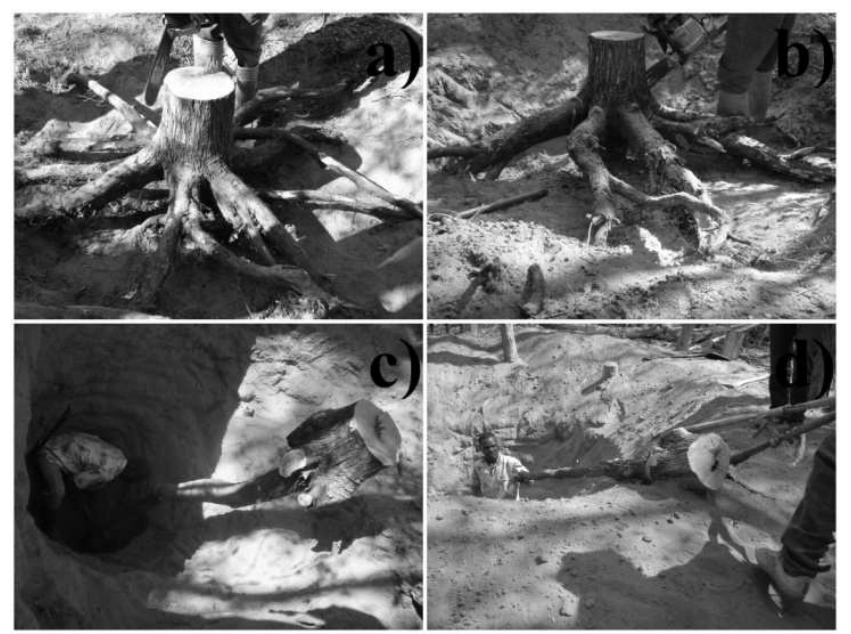

Figure 1. Separation of lateral roots from the taproot $(a, b)$, and removal of the taproot including the root collar and the stump $(c, d)$. 


\subsubsection{Stem Wood and Stem Bark}

Felled trees were scaled up to a $2.5 \mathrm{~cm}$ top diameter. The stem was defined as the length of trunk from the stump to the height that corresponded to $2.5 \mathrm{~cm}$ diameter. The remainder (from the height corresponding to $2.5 \mathrm{~cm}$ diameter to the tip of the tree) was considered a fine branch. The stem was divided into sections: the first with $1.1 \mathrm{~m}$ length, the second with $1.7 \mathrm{~m}$, and the remaining with $3 \mathrm{~m}$, except the last, the remainder, whose length depended on the length of the stem. Discs were removed on the bottom and top of the first section, and on the top of the remaining sections; i.e., discs were removed at heights of $0.2 \mathrm{~m}$ (stump height), $1.3 \mathrm{~m}$ (breast height), and $3 \mathrm{~m}$; with successive discs removed at intervals of $3 \mathrm{~m}$ to the top of the stem. Their fresh weights were measured using a digital scale.

Diameters over and under bark were taken from the discs in the North-South direction (previously marked on the standing tree) with the help of a ruler. The volumes over and under the bark of the stem were obtained by tallying the volumes of each section, calculated using Smalian's formula [6]. Bark volume was obtained from the difference between volume over bark and volume under bark.

The discs were dipped in drums filled with water, until constant weight (3 to 4 months), for their saturation and subsequent determination of the saturated volume and basic density. Saturated volume of the discs was obtained based on the water displacement method [35], using Archimedes' principle. This procedure was conducted twice: before and after debarking. Hence, we obtained saturated volume under and over bark.

Wood discs and respective barks were oven dried at $105^{\circ} \mathrm{C}$ to constant weight. Basic density was obtained by dividing oven dry weight of the discs (with and without bark) by the relevant saturated wood volume [36, 37]. Consequently, two distinct basic densities were calculated: (1) basic density of the discs with bark and (2) basic density of the discs without bark.
We estimated the basic density at the point of geometric centroid of each section, using the regression function of density over height [38]. This density value was established as representative of each section [38].

\subsubsection{Crown}

The crown was divided into two sub-components: branches and foliage. Primary branches, originating from the stem, were classified in two categories: large branches, or primary branches with diameter at insertion point on the stem $\geq 2.5 \mathrm{~cm}$, and fine branches, or those with diameter $<2.5 \mathrm{~cm}$. Large branches were sampled similarly to coarse roots, and fine branches and foliage were sampled similarly to fine roots.

\subsubsection{Tree Component Dry Weights}

We determined dry weight of the taproot, lateral roots, branches, and foliage by multiplying the ratio of oven-dry- to fresh-weight of each sample by the total fresh weight of the relevant component. Dry weights of the root system and crown were obtained by tallying the relevant sub-components' dry weights. Dry weights of each stem section (with and without bark) were obtained by multiplying respective densities by relevant stem section volumes. Stem (wood + bark) and stem wood dry weights were obtained by tallying each section's dry weight with and without bark, respectively. The dry weight of stem bark was determined from the difference between the dry weights of the stem and stem wood. We determined the dry weight of major components (root system, shoot system, and crown) and the whole tree by tallying the dry weights of their constituent components.

\subsection{Data Processing and Analysis}

We divided the stem of each felled tree into 10 segments of equal length, and we measured the diameter of each segment at the midpoint, starting from the bottom of the stem. Stem volume was computed using Hohenadl's method (Eq. 1) [39]:

$$
\mathrm{v}_{\mathrm{i} 2}=\frac{\Pi \mathrm{L}}{40}\left(\mathrm{~d}_{.05}^{2}+\mathrm{d}_{.15}^{2}+\mathrm{d}_{.25}^{2}+\mathrm{d}_{.35}^{2}+\mathrm{d}_{.45}^{2}+\mathrm{d}_{.55}^{2}+\mathrm{d}_{.65}^{2}+\mathrm{d}_{.75}^{2}+\mathrm{d}_{.85}^{2}+\mathrm{d}_{.95}^{2}\right)\left[\mathrm{m}^{3}\right]
$$

where $\mathrm{v}_{\mathrm{i} 2}$ is the stem volume of the $i^{\text {th }}$ tree from the second sampling phase, $L$ is the stem length, and $d_{i}$ is the diameter measured at the proportional distance along the stem of the $i^{\text {th }}$ tree.

Additionally, we determined merchantable stem volume of the trees of the second phase $\left(\mathrm{v}_{\mathrm{mi} 2}\right)$ (Eq. 2), defined as the volume of the stem excluding the portion with diameter $<$ $7 \mathrm{~cm}[11,18,19]$ and trees with $\mathrm{DBH}<7 \mathrm{~cm} \mathrm{[20]:}$

$$
\mathrm{v}_{\mathrm{mi} 2}=\frac{\Pi 1}{4} \sum_{\mathrm{i}=1}^{\mathrm{k}} \mathrm{d}_{\mathrm{m}}^{2}\left[\mathrm{~m}^{3}\right]
$$

where $d_{m}$ is the diameter at midpoint of each segment, 1 is the length of each segment, and $\mathrm{k}$ is the number of equal segments to the height that corresponded to $7 \mathrm{~cm}$ diameter.

Individual stem volume of the $i^{\text {th }}$ tree of the $j^{\text {th }}$ plot from the first sampling phase $\left(\mathrm{v}_{\mathrm{ij} 1}\right)$ was calculated using Eq. 3 as follows:

$$
\mathrm{v}_{\mathrm{ij} 1}=\frac{\Pi}{4} \mathrm{DBH}^{2} \times \mathrm{H} \times \mathrm{f}_{\mathrm{h}}\left[\mathrm{m}^{3}\right]
$$

where $\mathrm{H}$ is stem height and $\mathrm{f}_{\mathrm{h}}$ is the average Hohenadl's form factor obtained from the trees of the second sampling phase. Individual $\mathrm{f}_{\mathrm{h}}$ was computed using Eq. 4 as:

$$
\mathrm{f}_{\mathrm{h}}=0.1\left(1+\frac{\mathrm{d}_{.15}^{2}}{\mathrm{~d}_{.05}^{2}}+\frac{\mathrm{d}_{.25}^{2}}{\mathrm{~d}_{.05}^{2}}+\frac{\mathrm{d}_{.35}^{2}}{\mathrm{~d}_{.05}^{2}}+\frac{\mathrm{d}_{.45}^{2}}{\mathrm{~d}_{.05}^{2}}+\frac{\mathrm{d}_{.55}^{2}}{\mathrm{~d}_{.05}^{2}}+\frac{\mathrm{d}_{.65}^{2}}{\mathrm{~d}_{.05}^{2}}+\frac{\mathrm{d}_{.75}^{2}}{\mathrm{~d}_{.05}^{2}}+\frac{\mathrm{d}_{.85}^{2}}{\mathrm{~d}_{.05}^{2}}+\frac{\mathrm{d}_{.95}^{2}}{\mathrm{~d}_{.05}^{2}}\right) \text { [dimensionless] }
$$


Individual merchantable timber volume of the $i^{\text {th }}$ tree of the $j^{\text {th }}$ plot from the first sampling phase $\left(\mathrm{v}_{\mathrm{mij} 1}\right)$ was calculated using Eq. 5:

$$
\mathrm{v}_{\mathrm{mij} 1}=\mathrm{v}_{\mathrm{ij} 1} \times \mathrm{F}_{\text {timber }}\left[\mathrm{m}^{3}\right]
$$

where

$$
F_{\text {timber }}=\frac{\overline{\mathrm{v}}_{\mathrm{m} 2}}{\overline{\mathrm{v}}_{2}}=\frac{\sum_{\mathrm{i}=1}^{\mathrm{m}_{2}} \mathrm{v}_{\mathrm{mi} 2}}{\sum_{\mathrm{i}=1}^{\mathrm{m}_{2}} \mathrm{v}_{\mathrm{i} 2}} \text { [dimensionless] }
$$

is the fraction of the total stem that is merchantable timber, and $\overline{\mathrm{v}}_{\mathrm{m} 2}$ and $\overline{\mathrm{v}}_{2}$ are the average merchantable timber volume (per tree) and average stem volume (per tree) of the trees of the second phase, respectively.

The main auxiliary variables (the first-phase variables) consist of the average number of trees per hectare $\left(\mathrm{N}_{1}\right)$, and the stand-level stem volume $\left(\mathrm{m}^{3} \mathrm{ha}^{-1}\right)$, the last estimated from Eq. 7:

$$
\mathrm{V}_{1}=\frac{\sum_{\mathrm{j}=1}^{\mathrm{n}} \sum_{\mathrm{i}=1}^{\mathrm{m}_{\mathrm{j}}} \mathrm{v}_{\mathrm{ij} 1}}{\mathrm{n} \times \mathrm{a}}=\overline{\mathrm{v}}_{1} \times \mathrm{N}_{1}\left[\mathrm{~m}^{3} \mathrm{ha}^{-1}\right]
$$

where $\mathrm{m}_{\mathrm{j}}$ is the number of trees in the $j^{\text {th }}$ plot, $\mathrm{n}$ is the number of plots, a is the plot area (ha), $\overline{\mathrm{v}}_{1}$ is the average stem volume of the trees of the first phase $\left(\mathrm{m}^{3}\right)$, and $\mathrm{N}_{1}$ is the average number of trees per hectare estimated from the first sampling phase. Stem height of trees from the first phase was obtained by subtracting predefined stump height from the whole-tree height $(\mathrm{TH})$ to standardize the definitions of stem height and stem length (for phase-1 trees).

We determined tree component BEF-based biomass density or the ratio estimate of biomass density $\left(\mathrm{W}_{\mathrm{h}}\right)$ using Eq.8:

$$
\mathrm{W}_{\mathrm{h}}=\mathrm{BEF}_{\mathrm{h}} \times \mathrm{V}_{1}=\mathrm{W}_{\mathrm{hi}} \times \mathrm{N}_{1}\left[\mathrm{Mg} \mathrm{ha}^{-1}\right]
$$

where

$$
\mathrm{W}_{\mathrm{hi}}=\mathrm{BEF}_{\mathrm{h}} \times \overline{\mathrm{v}}_{1}[\mathrm{Mg}]
$$

is the estimated average component biomass per tree, which yields $\mathrm{W}_{\mathrm{h}}$ when multiplied by the number of trees per hectare $\left(\mathrm{N}_{1}\right) ; \mathrm{BEF}_{\mathrm{h}}$ is the vegetation $\mathrm{BEF}$ of the hth tree component (taproot+stump, lateral roots, root sytem, stem wood, stem bark, stem, branches, foliage, crown, shoot system or whole tree).

We calculated the sample $\mathrm{BEF}_{\mathrm{h}}$ using mean-of-ratios [7-9] (Eq.10) and ratio-of-means [10-14] (Eq. 11)

$$
\mathrm{BEF}_{\mathrm{h}}^{\mathrm{I}}=\frac{\sum_{\mathrm{i}=1}^{\mathrm{m}_{2}} \frac{\mathrm{w}_{\mathrm{hi} 2}}{\mathrm{v}_{\mathrm{i} 2}}}{\mathrm{~m}_{2}}=\frac{\sum_{\mathrm{i}=1}^{\mathrm{m}_{2}} \mathrm{BEF}_{\mathrm{hi}}}{\mathrm{m}_{2}}\left[\mathrm{Mg} \mathrm{m}^{-3}\right]
$$

$$
\mathrm{BEF}_{\mathrm{h}}^{\mathrm{II}}=\frac{\overline{\mathrm{w}}_{\mathrm{h} 2}}{\overline{\mathrm{v}}_{2}}=\frac{\sum_{\mathrm{i}=1}^{\mathrm{m}_{2}} \mathrm{w}_{\mathrm{hi} 2}}{\sum_{\mathrm{i}=1}^{\mathrm{m}_{2}} \mathrm{v}_{\mathrm{i} 2}}\left[\mathrm{Mg} \mathrm{m}^{-3}\right]
$$

where the superscripts I and II denote mean-of-ratios and ratio-of-means, respectively; therefore $\mathrm{BEF}_{\mathrm{h}}^{\mathrm{I}}$ and $\mathrm{BEF}_{\mathrm{h}}^{\mathrm{II}}$ correspond to $\mathrm{BEF}_{\mathrm{h}}$ computed using mean-of-ratios and ratio-of-means, respectively; $\mathrm{BEF}_{\mathrm{hi}}$ is the $\mathrm{BEF}$ of the $h^{\text {th }}$ component of the ith tree; $\mathrm{w}_{\mathrm{hi} 2}$ is the biomass of the $h^{\text {th }}$ component of the ith tree measured during the second phase; $\mathrm{V}_{\mathrm{i} 2}$ is the stem volume of the ith tree measured during the second phase; $\mathrm{m}_{2}$ represents the number of trees of the second sampling phase, and $\overline{\mathrm{w}}_{\mathrm{h} 2}$ is the average tree component biomass of the trees from the second sampling phase.

For regression-based tree component biomass density, we computed $\mathrm{W}_{\mathrm{hi}}$ and $\mathrm{W}_{\mathrm{h}}$ unsing Eq. 12 [1-6] and Eq. 13, respectively:

$$
\begin{gathered}
\mathrm{W}_{\mathrm{hi}}=\overline{\mathrm{W}}_{\mathrm{h} 2}+\mathrm{b}\left(\overline{\mathrm{v}}_{\mathrm{m} 1}-\overline{\mathrm{v}}_{\mathrm{m} 2}\right)[\mathrm{Mg}] \\
\mathrm{W}_{\mathrm{h}}=\mathrm{N}_{1} \times \mathrm{W}_{\mathrm{hi}}\left[\mathrm{Mg} \mathrm{ha}^{-1}\right]
\end{gathered}
$$

where

$$
\mathrm{b}=\mathrm{BEF}_{\mathrm{h}}^{\mathrm{III}}=\frac{\sum_{\mathrm{i}=1}^{\mathrm{m}_{2}}\left(\mathrm{w}_{\mathrm{hi2}}-\overline{\mathrm{w}}_{\mathrm{h} 2}\right)\left(\mathrm{v}_{\mathrm{mi} 2}-\overline{\mathrm{v}}_{\mathrm{m} 2}\right)}{\sum_{\mathrm{i}=1}^{\mathrm{m}_{2}}\left(\mathrm{v}_{\mathrm{mi} 2}-\overline{\mathrm{v}}_{\mathrm{m} 2}\right)^{2}}\left[\mathrm{Mg} \mathrm{m}^{-3}\right]
$$

is the regression slope.

Here the superscript III denotes regression estimators, so $\mathrm{BEF}_{\mathrm{h}}^{\mathrm{III}}$ is $\mathrm{BEF}_{\mathrm{h}}$ computed using regression estimators, and $\overline{\mathrm{V}}_{\mathrm{m} 1}$ and $\overline{\mathrm{V}}_{\mathrm{m} 2}$ are the average merchantable timber volume per tree of the first and second sampling phase, respectively.

The regression slope $b$ is an estimate of the change in tree component biomass $\left(\mathrm{w}_{\mathrm{h} 2}\right)$ when merchantable timber volume $\left(\mathrm{v}_{\mathrm{m} 2}\right)$ is increased by unity [2]. The same definition holds for $\mathrm{BEF}_{\mathrm{h}}$ with regard to stem volume; since in ratio estimators, the ratio $\mathrm{R}$ (e.g. $\mathrm{BEF}_{\mathrm{h}}$ ) is the regression slope when the regression line passes through the origin [40]. Therefore the regression slope b was, in this study, considered and treated as $\mathrm{BEF}_{\mathrm{h}}$ computed with aid to merchantable timber volume (Eq. 14).

Using mean-of-ratios estimators (I), the variance of the estimated $\mathrm{W}_{\text {hi }}$ (Eq. 9) was computed according to Freese $[1,3]$ as follows:

$$
\operatorname{VAR}_{\mathrm{W}_{\mathrm{hi}}}^{\mathrm{I}}=\overline{\mathrm{V}}_{1}^{2}\left(\frac{\mathrm{S}_{\mathrm{BEF}_{\mathrm{h}}}^{2}}{\mathrm{~m}_{2}}\right)\left(1-\frac{\mathrm{m}_{2}}{\mathrm{~m}_{1}}\right)+\frac{\mathrm{S}_{\mathrm{w}_{\mathrm{h} 2}}^{2}}{\mathrm{~m}_{1}}\left(1-\frac{\mathrm{m}_{1}}{\mathrm{M}}\right)\left[\mathrm{Mg}^{2}\right]
$$

Rearranging Eq. 9 as $\mathrm{BEF}_{\mathrm{h}}=\frac{\mathrm{W}_{\mathrm{hi}}}{\overline{\mathrm{V}}_{1}}$, the variance of the estimated $\mathrm{BEF}_{\mathrm{h}}$ becomes [4]: 


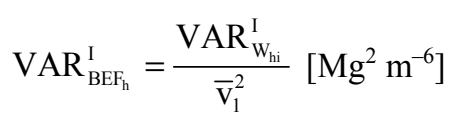

Similarly, the variance of the estimated $\mathrm{W}_{\mathrm{h}}$ is:

$$
\mathrm{VAR}_{\mathrm{W}_{\mathrm{h}}}^{\mathrm{I}}=\mathrm{N}_{1}^{2} \times \mathrm{VAR}_{\mathrm{W}_{\mathrm{hi}}}^{\mathrm{I}}\left[\mathrm{Mg}^{2} \mathrm{ha}^{-2}\right]
$$

For ratio-of-means (II) the variance of the estimated $\mathrm{W}_{\mathrm{hi}}$ (Eq. 9) was computed using Eq. 18 [1, 3]:

$$
\operatorname{VAR}_{\mathrm{W}_{\mathrm{hi}}}^{\mathrm{II}}=\left(1-\frac{\mathrm{m}_{2}}{\mathrm{~m}_{1}}\right)\left(\frac{\overline{\mathrm{v}}_{1}}{\overline{\mathrm{v}}_{2}}\right)^{2}\left(\frac{\mathrm{S}_{\mathrm{w}_{\mathrm{h} 2}}^{2}+\mathrm{BEF}_{\mathrm{h}}^{2} \times \mathrm{S}_{\mathrm{v}_{2}}^{2}-2 \times \mathrm{BEF}_{\mathrm{h}} \times \mathrm{S}_{\mathrm{yx}}}{\mathrm{m}_{2}}\right)+\frac{\mathrm{S}_{\mathrm{w}_{\mathrm{h} 2}}^{2}}{\mathrm{~m}_{1}}\left(1-\frac{\mathrm{m}_{1}}{\mathrm{M}}\right)\left[\mathrm{Mg}^{2}\right]
$$

Analogously, the variances of the estimated $\mathrm{BEF}_{\mathrm{h}}$ (Eq.11) and Wh are computed as in Eqs. 19 and 20

$$
\begin{gathered}
\operatorname{VAR}_{\mathrm{BEF}_{\mathrm{h}}}^{\mathrm{II}}=\frac{\mathrm{VAR}_{\mathrm{W}_{\mathrm{hi}}}^{\mathrm{II}}\left[\mathrm{Mg}^{2} \mathrm{~m}^{-6}\right]}{\overline{\mathrm{V}}_{1}^{2}} \\
\mathrm{VAR}_{\mathrm{W}_{\mathrm{h}}}^{\mathrm{II}}=\mathrm{N}_{1}^{2} \times \mathrm{VAR}_{\mathrm{W}_{\mathrm{hi}}}^{\mathrm{II}}\left[\mathrm{Mg}^{2} \mathrm{ha}^{-2}\right]
\end{gathered}
$$

$$
\mathrm{VAR}_{\mathrm{W}_{\mathrm{hi}}}^{\mathrm{III}}=\mathrm{S}_{\mathrm{r}}^{2}\left(\frac{1}{\mathrm{~m}_{2}}+\frac{\left(\overline{\mathrm{v}}_{\mathrm{m} 1}-\overline{\mathrm{v}}_{\mathrm{m} 2}\right)^{2}}{\mathrm{SS}_{\mathrm{v}_{2}}}\right)\left(1-\frac{\mathrm{m}_{2}}{\mathrm{~m}_{1}}\right)+\frac{\mathrm{S}_{\mathrm{w}_{\mathrm{h} 2}}^{2}}{\mathrm{~m}_{1}}\left(1-\frac{\mathrm{m}_{1}}{\mathrm{M}}\right)\left[\mathrm{Mg}^{2} \mathrm{~m}^{-6}\right]
$$

$$
\begin{gathered}
\operatorname{VAR}_{\mathrm{W}_{\mathrm{h}}}^{\mathrm{III}}=\mathrm{N}_{1}^{2} \times \mathrm{VAR}_{\mathrm{W}_{\mathrm{hi}}}^{\mathrm{III}}\left[\mathrm{Mg}^{2} \mathrm{ha}^{-2}\right] \\
\mathrm{VAR}_{\mathrm{b}}=\mathrm{VAR}_{\mathrm{BEF}_{\mathrm{h}}}^{\mathrm{III}}=\frac{\mathrm{S}_{\mathrm{r}}^{2}}{\mathrm{SS}_{\mathrm{v}_{2}}}\left[\mathrm{Mg}^{2} \mathrm{~m}^{-6}\right]
\end{gathered}
$$

where $\mathrm{S}_{\mathrm{BEF}_{\mathrm{h}}}^{2}=\frac{\sum \mathrm{BEF}_{\mathrm{hi}}^{2}-\frac{\left(\sum \mathrm{BEF}_{\mathrm{hi}}\right)^{2}}{\mathrm{~m}_{2}}}{\mathrm{~m}_{2}-1}$ is the variance of

$\mathrm{BEF}_{\mathrm{h}}$ for the second phase; $\mathrm{S}_{\mathrm{w}_{\mathrm{h} 2}^{2}}^{2}=\frac{\sum \mathrm{w}_{\mathrm{hi2}}^{2}-\frac{\left(\sum \mathrm{w}_{\mathrm{hi} 2}\right)^{2}}{\mathrm{~m}_{2}}}{\mathrm{~m}_{2}-1}$ is the variance of $\mathrm{w}_{\mathrm{h} 2} ; \mathrm{w}_{\mathrm{h} 2}$ is the component biomass for the second phase; $\mathrm{S}_{\mathrm{v}_{2}}^{2}=\frac{\sum \mathrm{v}_{\mathrm{i} 2}^{2}-\frac{\left(\sum \mathrm{v}_{\mathrm{i} 2}\right)^{2}}{\mathrm{~m}_{2}}}{\mathrm{~m}_{2}-1}$ is the variance of stem volume of the trees of the second phase $\left(\mathrm{v}_{2}\right) ; \mathrm{SS}_{\mathrm{v}_{2}}$ is the sum of squares of $\mathrm{v}_{2} ; \mathrm{S}_{\mathrm{yx}}$ is the covariance of $\mathrm{w}_{\mathrm{h} 2}$ and $\mathrm{v}_{2}$; $\mathrm{S}_{\mathrm{r}}^{2}=\frac{\mathrm{SS}_{\mathrm{w}_{\mathrm{h} 2}}-\frac{\left(\mathrm{SP}_{\mathrm{xy}}\right)^{2}}{\mathrm{SS}_{\mathrm{v} 2}}}{\mathrm{~m}_{2}-2}$ is the squared standard deviation from regression; $\mathrm{SS}_{\mathrm{w}_{\mathrm{h} 2}}$ is the sum of squares of $\mathrm{w}_{\mathrm{h} 2}$; and $\mathrm{SP}_{\mathrm{xy}}$ is the sum of products of $\mathrm{w}_{\mathrm{h} 2}$ and $\mathrm{v}_{2}$. The finite population correction factor $\left(1-\frac{\mathrm{m}_{1}}{\mathrm{M}}\right)$ was eliminated in all formulae because $m_{1}$ was very small relative to $M$, which was
Finally, using regression estimators (III), we calculated the variances of the estimated $\mathrm{W}_{\text {hi }}$ (Eq. 12) and $\mathrm{W}_{\mathrm{h}}$ (Eq. 13) also according to Freese [1, 3] (Eqs. 21 and 22) and the variance of the estimated regression slope $b$ according to Jayaraman [5] (Eq. 23):

unknown.

The square root of Eqs. 16, 19, 23 is the absolute standard error of the estimated $\mathrm{BEF}_{\mathrm{h}}$; and the square root of Eqs. 17, 20, 22 is the absolute standard error of the estimated $\mathrm{W}_{\mathrm{h}}$. Dividing these values by $\mathrm{BEF}_{\mathrm{h}}$ and $\mathrm{W}_{\mathrm{h}}$, respectively, then multiplying them by 100 , provides the respective percent standard error. The absolute and $95 \%$ confidence limits (CI) were computed by multiplying the absolute and percent standard error by the student's t-value.

\section{Results}

\subsection{Data Presentation}

The average number of trees per ha and average stem volume per ha were, approximately, $1237 \mathrm{ha}^{-1}(\mathrm{~min}=551$, $\max =2220, \mathrm{SD}=477, \mathrm{CV}=38.56 \%)$ and $115 \mathrm{~m}^{3} \mathrm{ha}^{-1}(\mathrm{~min}$ $=66.90, \max =170.47, \mathrm{SD}=25.44, \mathrm{CV}=22.09 \%)$, respectively. The average stem volume of the trees of the first and second sampling phase were, respectively, 0.0933 $\mathrm{m}^{3}(\min =0.0020, \max =1.6463, \mathrm{SD}=0.1153, \mathrm{CV}=$ $123.69 \%)$ and $0.1890 \mathrm{~m}^{3}(\mathrm{~min}=0.083, \max =0.5806, \mathrm{SD}=$ $0.1512, \mathrm{CV}=79.98 \%$ ), with an average Hohenadl's form factor of $0.4460(\mathrm{~min}=0.3002, \max =0.6128, \mathrm{SD}=0.0592$, $\mathrm{CV}=13.27 \%$ ). The merchantable timber volume of the trees of the first and second sampling phase were, respectively, $0.0899 \mathrm{~m}^{3}(\min =0.0019, \max =1.5866, \mathrm{SD}=$ $0.1112, \mathrm{CV}=123.62 \%)$ and $0.1821 \mathrm{~m}^{3}(\mathrm{~min}=0.0000$, $\max$ $=0.5784, \mathrm{SD}=0.1552, \mathrm{CV}=26.83 \%)$, with an $F_{\text {timber }}$ of 0.9638 . The average component dry weights per tree varied considerably (Table 1). 
Table 1. Average component dry weight (kg) per tree from the trees in the second phase, their standard deviation (SD), and coefficient of variation (CV).

\begin{tabular}{llllll}
\hline Tree component & Average & Minimum & Maximum & SD & CV (\%) \\
\hline Taproot & 23.7 & 1.4735 & 71.9260 & 18.9255 & 80.0187 \\
Lateral roots & 24.1 & 0.7455 & 100.8152 & 23.9455 & 99.4281 \\
Root system & $\mathbf{4 7 . 7}$ & $\mathbf{2 . 5 4 5 0}$ & $\mathbf{1 6 2 . 1 0 4 5}$ & $\mathbf{4 1 . 2 0 9 9}$ & $\mathbf{8 6 . 3 3 1 4}$ \\
Stem wood & 124.1 & 4.9469 & 357.3484 & 99.4971 & 80.1955 \\
Stem bark & 14.2 & 0.6774 & 55.8045 & 12.3722 & 87.1382 \\
Stem & $\mathbf{1 3 8 . 3}$ & $\mathbf{5 . 6 3 5 5}$ & $\mathbf{4 1 3 . 1 5 2 9}$ & $\mathbf{1 1 0 . 5 7 7 0}$ & $\mathbf{7 9 . 9 7 3 8}$ \\
Branches & 55.6 & 2.5827 & 211.3196 & 57.3549 & 103.1827 \\
Foliage & 2.8 & 0.3333 & 15.1000 & 2.4929 & 88.8182 \\
Crown & $\mathbf{5 8 . 4}$ & $\mathbf{3 . 0 3 7 7}$ & $\mathbf{2 1 6 . 6 9 4 6}$ & $\mathbf{5 9 . 0 7 6 9}$ & $\mathbf{1 0 1 . 1 7 2 0}$ \\
Shoot system & $\mathbf{1 9 6 . 7}$ & $\mathbf{9 . 8 2 3 0}$ & $\mathbf{5 9 0 . 8 6 2 8}$ & $\mathbf{1 6 3 . 7 1 3 5}$ & $\mathbf{8 3 . 2 4 7 3}$ \\
Total tree & $\mathbf{2 4 4 . 4}$ & $\mathbf{1 2 . 4 8 4 4}$ & $\mathbf{7 5 2 . 5 7 0 9}$ & $\mathbf{2 0 4 . 3 2 9 7}$ & $\mathbf{8 3 . 6 0 6 8}$ \\
\hline
\end{tabular}

The major components and their values are indicated in bold font.

\subsection{BEF and Biomass Estimates}

The $\mathrm{BEF}_{\mathrm{h}}$ values and the $\mathrm{BEF}$-based component biomass densities, and their uncertainties computed using the different estimators, are shown in Tables 2 and 3, respectively. The total tree and the shoot system BEFs obtained using mean-ofratios estimators were $>100 \%$ of the stem volume. The total tree biomass density was approximately $150 \mathrm{Mg} \mathrm{ha}^{-1}$, of which 80, 24, 56 and $20 \%$ were from the shoot system, crown, stem, and roots system, respectively. The uncertainties of the estimated $\mathrm{BEF}_{\mathrm{h}}$ and $\mathrm{W}_{\mathrm{h}}$, as measured by percent standard error SE $(\%)$, were $<5 \%$ for 7 of 11 tree components and $<10 \%$ for 10 of the 11 tree components; denoting high levels of precision.

Using ratio-of-means estimators the $\mathrm{BEF}_{\mathrm{h}}$ varied from 0.0149 for foliage to 1.2932 for total tree. As in the mean-of- ratios, the total tree and the shoot system BEFs were $>100 \%$ of the stem volume and the total tree biomass density was also approximately $150 \mathrm{Mg} \mathrm{ha}^{-1}$. The uncertainties (SE (\%)) of the estimated $\mathrm{BEF}_{\mathrm{h}}$ and $\mathrm{W}_{\mathrm{h}}$ were $<5 \%$ for 7 of the 11 components and $<8 \%$ for all tree components.

The $\mathrm{BEF}_{\mathrm{h}}$ values computed using regression estimators were similar to those obtained using mean-of-ratios and ratioof-means estimators. The estimated total tree and shoot system biomass densities were approximately, 157 and 127 $\mathrm{Mg} \mathrm{ha}{ }^{-1}$. The uncertainties, SE (\%), of the estimated $\mathrm{BEF}_{\mathrm{h}}$ were $<5 \%$ for 7 of the 11 components and $<7 \%$ for 10 of the 11 components. On the other hand, the uncertainties, SE (\%), of the estimated $\mathrm{W}_{\mathrm{h}}$ were $<10 \%$ for 7 of the 11 components and $<15 \%$ for all tree components.

Table 2. Component biomass expansion factors $\left(B E F_{h}\right)$, their variances $\left(V A R_{B E F}\right)$, standard errors (SE), and 95\% confidence intervals (CI), computed using mean-of-ratios, ratio-of-means and regression estimators.

\begin{tabular}{|c|c|c|c|c|c|c|c|}
\hline$\#$ & Tree component & $\mathrm{BEF}_{\mathrm{h}}\left(\mathrm{Mg} \mathrm{m}^{-3}\right)$ & $\operatorname{VAR}_{\mathrm{BEF}}\left(\mathrm{Mg}^{2} \mathrm{~m}^{-6}\right)$ & $\mathrm{SE}\left(\mathrm{Mg} \mathrm{m}^{-3}\right)$ & SE (\%) & $95 \% \mathrm{CI}\left(\mathrm{Mg} \mathrm{m}^{-3}\right)$ & $95 \%$ CI (\%) \\
\hline \multicolumn{8}{|c|}{ Mean-of-ratios estimates } \\
\hline 1 & Taproot + stump & 0.1407 & $3.6 \mathrm{E}-05$ & 0.0060 & 4.2382 & \pm 0.0119 & \pm 8.4764 \\
\hline 2 & Lateral roots & 0.1162 & $4.4 \mathrm{E}-05$ & 0.0067 & 5.7232 & \pm 0.0133 & \pm 11.4465 \\
\hline 3 & Root system $(1+2)$ & 0.2569 & 1.0E-04 & 0.0100 & 3.8930 & $\pm \mathbf{0 . 0 2 0 0}$ & \pm 7.7860 \\
\hline 4 & Stem wood & 0.6569 & $3.6 \mathrm{E}-04$ & 0.0191 & 2.9046 & \pm 0.0382 & \pm 5.8092 \\
\hline 5 & Stem bark & 0.0765 & $1.3 \mathrm{E}-05$ & 0.0036 & 4.7534 & \pm 0.0073 & \pm 9.5068 \\
\hline 6 & Stem $(4+5)$ & 0.7334 & 4.4E-04 & 0.0210 & 2.8615 & \pm 0.0420 & \pm 5.7230 \\
\hline 8 & Foliage & 0.0242 & $6.6 \mathrm{E}-06$ & 0.0026 & 10.6242 & \pm 0.0051 & \pm 21.2483 \\
\hline 9 & Crown $(7+8)$ & 0.3170 & 3.6E-04 & 0.0190 & 5.9973 & $\pm \mathbf{0 . 0 3 8 0}$ & \pm 11.9946 \\
\hline 10 & Shoot system $(6+9)$ & 1.0504 & $1.2 E-03$ & 0.0340 & 3.2345 & \pm 0.0679 & \pm 6.4690 \\
\hline 11 & Total tree $(3+10)$ & 1.3072 & $1.8 E-03$ & 0.0428 & 3.2736 & \pm 0.0856 & $\pm \mathbf{6 . 5 4 7 2}$ \\
\hline \multicolumn{8}{|c|}{ Ratio-of-means estimates } \\
\hline 1 & Taproot + stump & 0.1251 & $2.9 \mathrm{E}-05$ & 0.0054 & 4.3388 & \pm 0.0109 & \pm 8.6775 \\
\hline 2 & Lateral roots & 0.1274 & 4.6E-05 & 0.0068 & 5.3245 & \pm 0.0136 & \pm 10.6490 \\
\hline 5 & Stem bark & 0.0751 & $1.4 \mathrm{E}-05$ & 0.0037 & 4.9522 & \pm 0.0074 & \pm 9.9043 \\
\hline 6 & Stem $(4+5)$ & 0.7316 & $5.2 E-04$ & 0.0228 & 3.1195 & \pm 0.0456 & \pm 6.2389 \\
\hline 7 & Branches & 0.2941 & $3.9 \mathrm{E}-04$ & 0.0197 & 6.6939 & \pm 0.0394 & \pm 13.3878 \\
\hline 8 & Foliage & 0.0149 & $1.4 \mathrm{E}-06$ & 0.0012 & 7.8790 & \pm 0.0023 & \pm 15.7579 \\
\hline 9 & Crown $(7+8)$ & 0.3090 & 4.0E-04 & 0.0201 & 6.5118 & \pm 0.0402 & \pm 13.0236 \\
\hline 10 & Shoot system $(6+9)$ & 1.0406 & 1.3E-03 & 0.0366 & 3.5201 & \pm 0.0733 & \pm 7.0402 \\
\hline 11 & Total tree $(3+10)$ & 1.2932 & 2.1E-03 & 0.0457 & 3.5343 & $\pm \mathbf{0 . 0 9 1 4}$ & \pm 7.0685 \\
\hline \multicolumn{8}{|c|}{ Regression estimates } \\
\hline 1 & Taproot + stump & 0.1113 & 2.7E-05 & 0.0052 & 4.6931 & \pm 0.0104 & \pm 9.3861 \\
\hline 2 & Lateral roots & 0.1418 & 4.1E-05 & 0.0064 & 4.4969 & \pm 0.0128 & \pm 8.9939 \\
\hline 3 & Root system $(1+2)$ & 0.2531 & 7.1E-05 & 0.0084 & 3.3266 & \pm 0.0168 & \pm 6.6532 \\
\hline 4 & Stem wood & 0.6262 & $2.1 \mathrm{E}-04$ & 0.0144 & 2.3006 & \pm 0.0288 & \pm 4.6011 \\
\hline
\end{tabular}




\begin{tabular}{|c|c|c|c|c|c|c|c|}
\hline \# & Tree component & $\mathrm{BEF}_{\mathrm{h}}\left(\mathrm{Mg} \mathrm{m}^{-3}\right)$ & $\operatorname{VAR}_{\text {BEF }}\left(M^{2} m^{-6}\right)$ & SE $\left(M ~ m^{-3}\right)$ & SE (\%) & $95 \% \mathrm{CI}\left(\mathrm{Mg} \mathrm{m}^{-3}\right)$ & $95 \%$ CI (\%) \\
\hline 5 & Stem bark & 0.0703 & $1.6 \mathrm{E}-05$ & 0.0039 & 5.6200 & \pm 0.0079 & \pm 11.2400 \\
\hline 6 & Stem $(4+5)$ & 0.6965 & $2.5 \mathrm{E}-04$ & 0.0158 & 2.2624 & $\pm \mathbf{0 . 0 3 1 5}$ & \pm 4.5248 \\
\hline 7 & Branches & 0.3136 & $4.2 \mathrm{E}-04$ & 0.0205 & 6.5404 & \pm 0.0410 & \pm 13.0807 \\
\hline 8 & Foliage & 0.0105 & $1.6 \mathrm{E}-06$ & 0.0013 & 12.1947 & \pm 0.0026 & \pm 24.3894 \\
\hline 9 & Crown $(7+8)$ & 0.3240 & 4.4E-04 & 0.0209 & 6.4639 & \pm 0.0419 & $\pm \mathbf{1 2 . 9 2 7 7}$ \\
\hline 10 & Shoot system $(6+9)$ & 1.0205 & $7.8 \mathrm{E}-04$ & 0.0280 & 2.7449 & $\pm \mathbf{0 . 0 5 6 0}$ & \pm 5.4898 \\
\hline 11 & Total tree $(3+10)$ & 1.2736 & $1.2 \mathrm{E}-03$ & 0.0350 & 2.7475 & $\pm \mathbf{0 . 0 7 0 0}$ & $\pm \mathbf{5 . 4 9 5 0}$ \\
\hline
\end{tabular}

The major components and their values are indicated in bold font.

Table 3. Component biomass density $\left(W_{h}\right)$, their variances $\left(V A R_{W h}\right)$, standard errors $(S E)$, and 95\% confidence intervals $(C I)$, computed using mean-of-ratios, ratio-of-means and regression estimators.

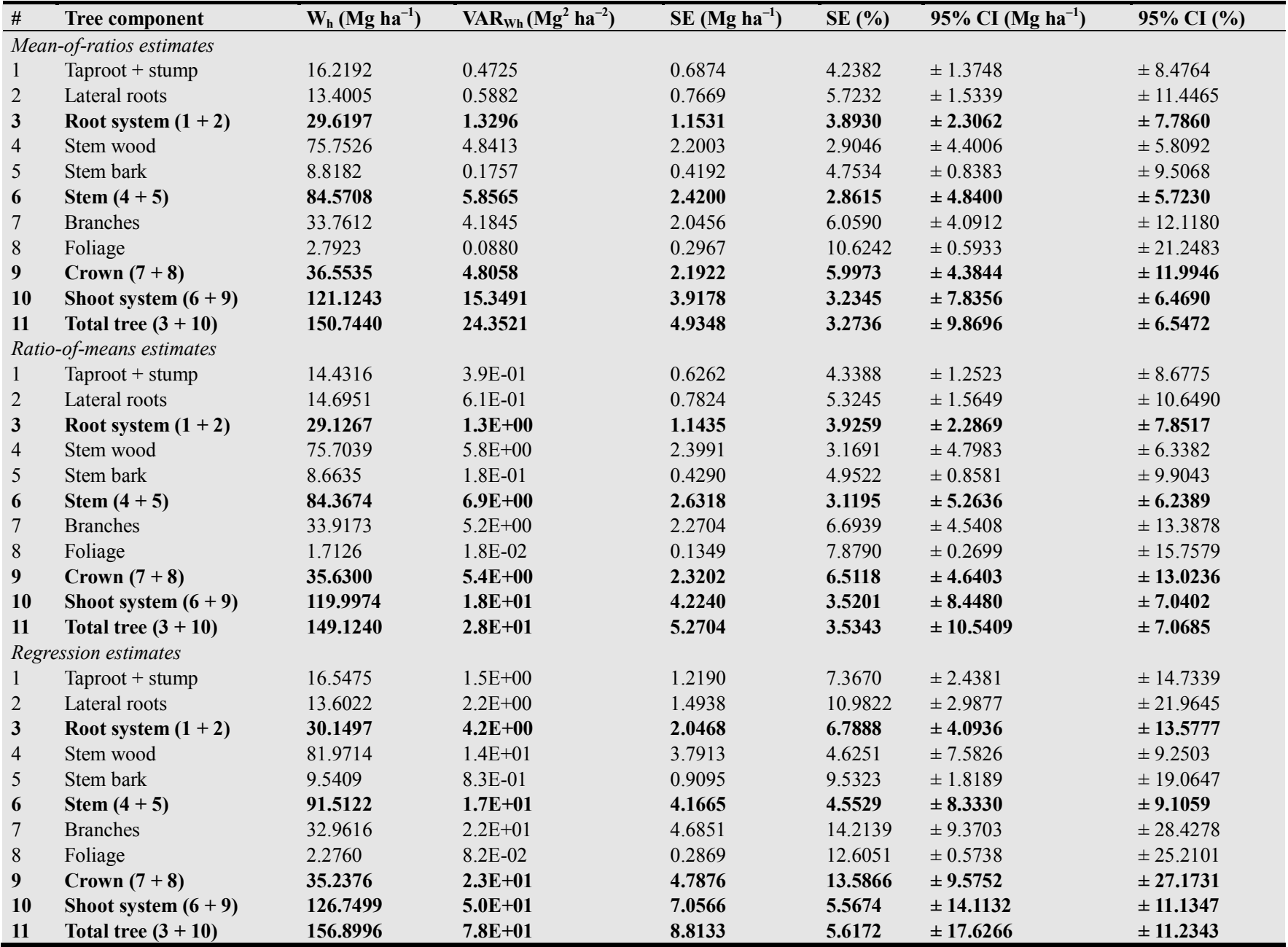

The major components and their values are indicated in bold font.

\section{Discussion}

\subsection{BEF and Biomass Density}

The BEF values computed from different estimators are consistent with one another. The reasons the ratio-based BEFs (either mean-of-ratios or ratio-of-means) were similar to regression-based BEFs involve the fact that $F_{\text {timber }}$ is very close to 1 [16], which causes stem volume values to be close to merchantable timber values; as well as the fact that in phase two only 7 trees were not considered in calculation of merchantable timber volumes because their DBH was $<7 \mathrm{~cm}$.

However, it should be mentioned that, in most tropical tree species, and specially in broadleaf species (as opposed to conifers), procuring a minimum top diameter of $7 \mathrm{~cm}$ to define merchantable tree height, and thus, merchantable timber volume, is somewhat impractical because the merchantable height is limited by branching, irregular form or defects, which can cause the top diameter to be substantially larger than $7 \mathrm{~cm}$ (and inconsistent in each tree), and thus, $\mathrm{F}_{\text {timber }}$ much smaller than 1 . This will lead to larger values of $\mathrm{BEF}$ and overestimation of biomass densities. On the other hand, BEF values computed using merchantable timber volume as defined in this study, disregard younger trees (DBH $<7 \mathrm{~cm}$ ); which are found to be very important in the United Nations Framework Convention on Climate 
Change (UNFCCC) reporting process [41]. Moreover, merchantable tree height (i.e., to $7 \mathrm{~cm}$ top diameter) measurement/estimation (and thus, merchantable timber volume) in standing trees is subjective and more susceptible to measurement error than total tree height, since the $7 \mathrm{~cm}$ top diameter on the stem is more difficult to identify than the tip of the tree.

The biomass densities computed based on mean-of-ratios are slightly larger than those based on ratio-of-means, except for root system and branches. On the other hand, considerable discrepancies were found between ratio-based (either mean-of-ratios or ratio-of-means) and regressionbased biomass densities, with regression-based biomass densities calculated as larger than ratio-based ones, except for 3 components. However, despite those discrepancies, the component biomass densities derived from the 3 estimators lie in any estimator's 95\% CI.

Although the BEF values obtained from the different estimators are similar, the regression-based BEFs (i.e., computed based on merchantable timber volume) exclude the portion of the stem with diameter $<7 \mathrm{~cm}$ and the trees with $\mathrm{DBH}<7 \mathrm{~cm}$; and therefore, might not be suitable for estimation of $\mathrm{C}$ storage in forested ecosystems, as claimed by Black et al. [20], especially in cases where $F_{\text {timber }}$ is found to be much smaller than 1 .

The estimated total tree and aboveground BEF values by any of the estimators are consistent with those obtained by Ducta et al. [8], Marková and Pokorný [9], Lehtonen et al. [11], Cháidez [13], Segura and Kanninen [42], Kamelarczyk [43], and Sanquetta et al. [44].

The aboveground biomass (AGB) densities calculated by any estimator are in agreement with those estimated for Mozambique by Brown [45] for dense forests growing in moist-dry season $\left(120 \mathrm{Mg} \mathrm{ha}^{-1}\right)$ and in moist-short dry season $\left(130 \mathrm{Mg} \mathrm{ha}^{-1}\right)$, but are higher compared to dense forests growing in dry seasons $\left(70 \mathrm{Mg} \mathrm{ha}^{-1}\right)$. However, the AGB density estimates based on mean-of-ratios and ratiosof-means estimators (121 and $120 \mathrm{Mg} \mathrm{ha}^{-1}$, respectively) are much closer to those of dense forests growing in moist-dry season; and the regression-based AGB densities (127 $\mathrm{Mg} \mathrm{ha}^{-1}$ ) are close to those of dense forests growing in moist-short dry season. Yet, mecrusse woodlands are typically from dry season regions [22-27], implying that the biomass productivity of mecrusse woodlands are, approximately, twice as larger than the average productivity of dense forests growing in dry seasons in Mozambique.

Our estimates of AGB densities are much larger than the estimates of miombo woodlands, the primary woodlands in Mozambique [46]. Mate et al. [47] found that the AGB density in miombo woodlands in Inhambane and Sofala provinces were $27.3 \mathrm{Mg} \mathrm{ha}^{-1}$; and Ribeiro et al. [48] found that the tree biomass density in miombo woodlands in Niassa National Reserve were approximately $59 \mathrm{Mg} \mathrm{ha}^{-1}$. Low stem density (380-400 $\left.\mathrm{ha}^{-1}\right)$ and basal area $\left(7-19 \mathrm{~m}^{2} \mathrm{ha}^{-1}\right)$ in miombo woodlands [49] can explain the lower estimates for biomass densities compared to our estimates within mecrusse woodlands (1237 ha $\mathrm{ha}^{-1}$ and $22 \mathrm{~m}^{2} \mathrm{ha}^{-1}$, respectively).
For the different estimators used to estimate biomass densities, the property of additivity was achieved automatically for the major tree components (root system, shoot system, stem, and crown) and for total tree biomass; i.e., the biomass estimate of the relevant minor tree components' sum to the estimate of relevant major component biomasses and the total tree biomass, which is a desired and logical feature. This is so because stem volume (for ratio estimators) or merchantable timber volume (for regression estimators) is the single auxiliary variable for all tree components.

\subsection{Uncertainty}

The percent standard errors in the regression-based BEFs are smaller (more precise) than those of the ratio-based ones, in 8 tree components for mean-of-ratios and 6 tree components for ratio-of-means. The BEFs computed based on mean-of-ratios are more precise in 9 components than are those computed based on ratio-of-means estimators. On the other hand, the regression-based tree component biomass densities are less precise (more uncertain) than the ratiobased ones (both mean-of-ratios and ratio-of-means).

The estimated uncertainty (SE (\%)) in our ratio-based BEF values $(2.9 \%-10.6 \%$ for mean-of-ratios; and $3.1 \%-7.9 \%$ for ratio-of-means) and regression-based BEF values $(2.7 \%-$ $12.1 \%$ ) were lower than those of Lehtonen et al. [11, 19] $(3 \%-21 \%)$, and Jalkanen et al. [7] (4\%-13\%). The component biomass and stem volume values used here to calculate BEF were obtained directly using destructive sampling, whereas those by Lehtonen et al. [11, 19] and Jalkanen et al. [7] were based on values obtained indirectly using regression models. These different approaches might explain the differences among BEF estimates and the higher uncertainty reported by those authors, because they also incorporate uncertainty from the regression models.

The total uncertainty of the estimate of AGB biomass density, as measured by SE (\%) and $95 \% \mathrm{CI}$, using ratio estimators (either mean-of-ratios or ratio-of-means) and regression estimators, were approximately four-fold and twofold smaller, respectively, than those obtained by Chave et al. [50] $(\mathrm{SE}=24 \%)$ and Brown et al. [51] $(95 \% \mathrm{CI}= \pm$ $20 \%$ ). This denotes that our estimates of ABG biomass are two to four times more precise and accurate than those obtained by Chave et al. [50] and Brown et al. [51].

The low level of uncertainty in our BEF and biomass estimates is, presumably, attributed to the homogeneity of mecrusse woodlands and site characteristics, as A. johnsonii is the only canopy species in mecrusse woodlands, and because our phase two sample size $(n=93)$ is large, as defined by Freese [1, 3], Husch et al. [6], Stellingwerf [52], and Stauffer [53], in which the sample size should be $>30$ to be considered large. Stellingwerf [52] suggested that the 95\% CI should not exceed $\pm 20 \%$ of the mean. Our $95 \%$ CI for estimates of component BEFs fell well within these accepted limits $(<20 \%)$; except for foliage BEF, in which it was $21.25 \%$ and $24.39 \%$ for ratio-of-means-based and regression-based $\mathrm{BEF}$, respectively. 


\section{Conclusion}

The computation of BEF using merchantable timber volume should utilize regression estimators, not ratio estimators as usually done. Tree component biomass densities computed with the aid of regression-based BEFs were found to be more uncertain than those computed with the aid of ratio-based BEFs. BEFs computed using merchantable timber volume (regression-based BEFs) are subjective and more susceptible to errors, as the definition of merchantable stem height is subjective, and susceptible to errors and personal judgement, especially in standing trees; and the use of a fixed top diameter to define merchantable height is limited by branching, irregular form, or defects in most tropical tree species and particularly in broadleaf tree species. Furthermore, BEFs computed using merchantable timber volume exclude trees that have not achieved a predefined minimum merchantable DBH and the portion of the tree without minimum top diameter, and that therefore, might not be suitable for estimation of $\mathrm{C}$ storage in forested ecosystems.

\section{Acknowledgments}

This study was funded by the Swedish International Development Cooperation Agency (SIDA).

\section{References}

[1] F. Freese, Elementary Forest Sampling, United States Department of Agriculture, Washington DC; 1962.

[2] W. G. Cochran, Sampling Techniques, John Wiley \& Sons, New York, $3^{\text {rd }}$ edition, 1977.

[3] F. Freese, Statistics for Land Managers, Paeony Press, Edinburgh, 1984.

[4] P. G. de Vries, Sampling Theory for Forest Inventory, Springer-Verlag, New York, 1986.

[5] K. Jayaraman, A Statistical Manual for Forestry Research, FORSPA-FAO, Bangkok, 2000.

[6] B. Husch, T. W. Beers, and J. A. Kershaw Jr., Forest Mensuration, John Wiley \& Sons, New York, USA, $4^{\text {th }}$ edition, 2003.

[7] A. Jalkanen, R. Mäkipää, G. Stahl, A. Lehtonen, and H. Petersson, "Estimation of the biomass stock of trees in Sweden: comparison of biomass equations and age-dependent biomass expansion factors", Ann. For. Sci., vol. 62, pp. 845$851,2005$.

[8] I. Dutca, I. V. Abrudan, P. T. Stancioiu, V. Blujdea, "Biomass conversion and expansion factors for young Norway spruce (Picea abies (L.) Karst.) trees planted on non-forest lands in Eastern Carpathians", Not Bot Hort Agrobot Cluj, vol. 38, no. 3, pp. 286-292, 2010.

[9] I. Marková, and R. Pokorný, "Allometric relationships for the estimation of dry mass of aboveground organs in young highland Norway spruce stand", Acta Univ Agric Silvic Mendel Brun, vol. 59, no. 6, pp. 217-224, 2011.
[10] E. M. Nogueira, P. M. Fearnside, B. W. Nelson, R. I. Barbosa, and E. W. H. Keizer, "Estimates of forest biomass in the Brazilian Amazon: New allometric equations and adjustments to biomass from wood-volume inventories", Forest Ecology and Management, vol. 256, pp. 1853-1867, 2008.

[11] A. Lehtonen, R. Mäkipää, J. Heikkinen, R. Sievänen, and J. Lisk, "Biomass expansion factors (BEFs) for Scots pine, Norway spruce and birch according to stand age for boreal forests", . Forest Ecology and Management, vol. 188, pp. 211-224, 2004

[12] P. Soares, and M. Tome, "Biomass expansion factores for Eucalyptus globulus stands in Portugal”, Forest Systems, vol. 21, no. 1, pp. 141-152, 2012.

[13] J. J. N. Cháidez, "Allometric equations and expansion factors for tropical dry forest trees of Eastern Sinaloa, Mexico", Trop Subtrop Agroecosys, vol. 10, pp. 45-52, 2009.

[14] F. M. Silva-Arredondo, and J. J. N. Návar-Cháidez, "Factores de expansión de biomasa en comunidades florestales templadas del Norte de Durango, México", Rev Mex Cien For, vol. 1, no. 1, pp. 55-62, 2010.

[15] S. Brown, "Measuring carbon in forests: current and future challenges", Environ Pollut, vol. 116, pp. 363-372, 2002.

[16] P. E. Levy, S.E. Hale, and B. C. Nicoll, "Biomass expansion factors and root: shoot ratios for coniferous tree species in Great Britain”, Forestry, vol. 77, no. 5, pp. 421-430, 2004.

[17] Z. Somogyi, E. Cienciala, R. Mäkipää, P. Muukkonen, A. Lehtonen, and P. Weiss, "Indirect methods of large-scale forest biomass estimation”, Eur J Forest Res, vol. 126, pp. 197-207, 2007.

[18] P. N. Edwards, and J. M. Christie, Yield models for forest management, HMSO, London, 1981.

[19] A. Lehtonen, E. Cienciala, F. Tatarinov, R. Mäkipää, "Uncertainty estimation of biomass expansion factors for Norway spruce in the Czech Republic", Ann For Sci, vol. 64, pp. 133-140, 2007.

[20] K. Black, B. Tobin, G. Siaz, K. A. Byrne, and B. Osborne, "Improved estimates of biomass expansion factors for Sitka spruce", Irish Forestry, pp. 50-65, n.d.

[21] J. Mantilla, and R. Timane, Orientação para maneio de mecrusse, SymfoDesign Lda, Maputo, Mozambique, p. 1, 2005.

[22] Dinageca, Mapa Digital de Uso e Cobertura de Terra, Cenacarta, Maputo, Moçambique, 1990.

[23] Mae, Perfil do Distrito de Chibuto, Província de Gaza, Mae, Maputo, Moçambique, 2005.

[24] Mae, Perfil do Distrito de Mandhlakaze, Província de Gaza, Mae, Maputo, Moçambique, 2005.

[25] Mae, Perfil do Distrito de Panda, Provincia de Inhambane, Mae, Maputo, Moçambique, 2005.

[26] Mae, Perfil do Distrito de Funhalouro, Província de Inhambane, Mae, Maputo, Moçambique, 2005.

[27] Mae, Perfil do Distrito de Mabote, Província de Inhambane, Mae, Maputo, Moçambique, 2005. 
[28] T.M. Magalhães, "Allometric equations for estimating belowground biomass of Androstachys johnsonii Prain", Carbon Balance and Management, 10:16, 2015.

[29] T.M. Magalhães, T. Seifert, "Estimation of tree biomass, carbon stocks, and error propagation in mecrusse woodlands", Open Journal of Forestry vol. 5, pp. 471-488, 2015.

[30] T.M. Magalhães, T. Seifert, "Biomass modelling of Androstachys johnsonii Prain - a comparison of three methods to enforce additivity", International Journal of Forestry Research vol. 2015, pp.1-17, 2015.

[31] T.M. Magalhães, T. Seifert, "Tree component biomass expansion factors and root-to-shoot ratio of Lebombo ironwood: measurement uncertainty", Carbon Balance and Management 10: 9, 2015.

[32] T.M. Magalhães, T. Seifert, "Below- and aboveground architecture of Androstachys johnsonii Prain: Topological analysis of the root and shoot systems", Plant and Soil, 2015. DOI $10.1007 / \mathrm{s} 11104-015-2527-0$

[33] FAO, FAO Map of World Soil Resources, Italy, Rome, 2003.

[34] B. R. Parresol, "Additivity of nonlinear biomass equations", Can. J. For. Res., vol. 31, pp. 865-878, 2001.

[35] M. A. M. Brasil, R. A. A. Veiga, and J. L. Timoni, "Erros na determinação da densidade básica da madeira", CERNE, vol. 1, no. 1, pp. 55-57, 1994.

[36] I. A. Gier, Forest mensuration (fundamentals); International Institute for Aerospace Survey and Earth Sciences (ITC), The Netherlands, p. 20, 21, 1992.

[37] J. Bunster, Commercial timbers of Mozambique, Technological catalogue, Traforest Lda, Maputo, Mozambique, 2006.

[38] T. Seifert, and S. Seifert, "Modelling and simulation of tree biomass", in Bioenergy from Wood: Sustainable Production in the Tropics; T. Seifert, Ed., pp. 42-65, Springer, Managing Forest Ecosystems, vol. 26, 2014.

[39] S. A. Machado, A. Figueiredo Filho, Dendrometria, Unicentro, Paraná, Brazil, 2005.

[40] E. W. Johnson, Forest Sampling Desk Reference, CRC Press LLC, Florida, USA, 2000.

[41] K. Black, B. Tobin, G. Siaz, K. A. Byrne, and B. Osborne, "Allometric regressions for an improved estimate of biomass expansion factors for Ireland based on a Sitka spruce chronosequence", Irish Forestry, Vol. 61, no. 1, pp. 50-65, 2004.

[42] M. Segura, M. Kanninen, "Allometric models for tree volume and total aboveground biomass in a tropical humid forest in Costa Rica”, Biotropica, vol. 37, no. 1, pp. 2-8, 2005.

[43] K. B. F. Kamelarczyk, "Carbon stock assessment and modelling in Zambia: a UN-REDD programme study", United Nations-Reducing Emissions from Deforestation and Forest Degradation, Zambia, 2009.

[44] C. R. Sanquetta, A. P. D. Corte, F. Silva, "Biomass expansion factors and root-to-shoot ratio for Pinus in Brazil", Carbon Balance and Management, vol. 6, pp. 1-8, 2011.

[45] S. Brown, "Estimating biomass and biomass change of tropical forests: a primer," FAO Forest Paper 134, 1997.

[46] A. A. Sitoe, and N. S. Ribeiro, Miombo Book Project (Case Study of Mozambique), Universidade Eduardo Mondlane (UEM). Maputo, Mozambique, 1995.

[47] R. Mate, T. Johansson, and A. Sitoe, "Biomass equations for Tropical Forest tree species in Mozambique", Forests, vol. 5, pp. 535-556, 2014.

[48] N. S. Ribeiro, C. N. Matos, I. R. Moura, R. A. WashingtonAllen, and A. I. Ribeiro (2013) "Monitoring vegetation dynamics and carbon stock density in miombo woodlands", Carbon Balance and Management, vol. 8, no. 1, pp. 1-9, 2014.

[49] N. Ribeiro, A. A. Sitoe, B. S. Guedes, and C. Staiss, Manual de Silvicultura Tropical, Food and Agriculture Organisation of the United Nations, Maputo, Mozambique, 2002.

[50] J. Chave, R. Condic, S. Aguilar, A. Hernandez, S. Lao, and R. Perez, "Error propagation and scaling for tropical forest biomass estimates", Phil. Trans. R. Soc. Lond. B, vol. 309, pp. 409-420, 2004

[51] I. F. Brown, L. A. Martinelli, W. W. Thomas, M. Z. Moreira, C. A. C. Ferreira, R. A. Victoria, "Uncertainty in the biomass of Amazonian forests: An example from Rondônia, Brazil", Forest Ecology and Management, vol. 75, pp. 175-189, 1995.

[52] D. A. Stellingwerf, Forest inventory and remote sensing, International Training Centre for Aerial Survey (ITC), Enschede, 1994.

[53] H. B. Stauffer, Some sample size tables for forest sampling, Ministry of Forests, British Columbia, Canada, 1983. 